\title{
The Slime Production by Yeasts Isolated from Subclinical Mastitic Cows
}

\author{
Süheyla Türkyılmaz ${ }^{1}$, Seyhan Kaynarca² \\ ${ }^{1}$ Department of Microbiology, Veterinary Faculty, Adnan Menderes University, \\ Aydin, Turkey \\ ${ }^{2}$ Adnan Menderes University Health Sciences Institute, Aydin, Turkey
}

Received March 3, 2009

Accepted November 24, 2010

\begin{abstract}
The aim of this study was to isolate yeasts from subclinical mastitic cows and to investigate the slime production by the isolated yeasts. The material used in this study included 339 milk samples from 152 dairy cattle with subclinical mastitis. Milk was plated onto blood agar, MacConkey agar and Sabouraud dextrose agar. Forty-one samples (12.1\% of total milk samples) were found positive for the yeast by API $20 \mathrm{C}$ AUX identification system. The isolated yeasts were classified into four genera of Candida, Trichosporon, Cryptococcus and Saccharomyces. The Candida species were following: C. krusei, C. kefyr, C. guilliermondii, C. famata, C. rugosa and C. utulis. Other yeasts were identified as Trichosporon mucoides, T. asahii, Cryptococcus laurentii, C. neoformans and Saccharomyces cerevisiae.

Slime production was tested on Congo red brain heart infusion agar and evaluated according to Congo red phenomenon. Fifteen $(36.6 \%)$ strains were slime factor positive: seven were $C$. krusei, four $C$. kefyr, one $C$. guilliermondii, one $C$. famata, one $T$. asahii, and one C. laurentii. The results of the present study indicate that yeast mastitis is significant for causing economic losses and slime production is mostly found in non-albicans Candida species. Therefore, non-albicans Candida species should be examined for slime production.
\end{abstract}

Mastitis, cows, milk, yeast, slime production

Mastitis, which has multiple and complex aetiology, is a common syndrome among bovines and inflicts losses on livestock owners. The mastitis cases are infectious in nature and are usually caused by bacteria, fungi or yeasts, some algae, and other microorganisms as viruses (Watts 1988; Chahota et al. 2001).

Mastitis either occurs with clinical symptoms (clinical mastitis) or without them (subclinical mastitis). The reduction in milk production attributed to subclinical mastitis may account for $70 \%-80 \%$ of the total losses (Philpot and Nickers on 1991). Somatic cell counts (SCC) in milk may be used to identify the presence of subclinical mastitis. California mastitis test (CMT), a qualitative measurement of the SCC in milk, is a screening test for mastitis that can be used easily. Although CMT and SCC are used for the determination of mastitis, the definitive test for the diagnosis of mastitis is bacteriological isolation and identification (Leslie et al. 2002).

Mycotic mastitis had been documented to be caused by various genera of yeasts. However, the most frequently encountered species are Candida spp., Trichosporon spp., Cryptococcus spp., Saccharomyces spp., Aspergillus spp. (Farnsworth et al. 1972; Costa et al. 1993; Bourtzi-Hatzopoulou et al. 2003; Santos and Marin 2005; Krukowski et al. 2006).

Fungi are usually considered an environmental mastitis and they are usual agent in cows' mastitis (Watts 1988; Sheena and Siegler 1995). Fungal infections are predominantly caused by yeasts of the genus Candida (Watts 1988) and several species of yeast have been reported in many countries as causative of mastitis. Bovine yeast mastitis was reported to be responsible for $10 \%$ in Brazil (Costa et al. 1993), 9.6\% in Poland (Krukowski et al. 2000), 6.2\% in Greece (Bourtzi-Hatzopoulou et al. 2003) of all mastitis cases.

Address for correspondence:

Dr. Süheyla Türkyılmaz

Department of Microbiology

Faculty of Veterinary Medicine

University of Adnan Menderes

09010 Aydin,TURKEY

Phone: +902562470700

Fax: +902562470720

E-mail: suhturkyilmaz@yahoo.com

http://www.vfu.cz/acta-vet/actavet.htm 
Candida spp. produces large quantities of viscid material in glucose containing solutions. A biofilm (or slime) is a community of microorganisms and their extracellular polymers that are attached to a surface. The ability to form biofilms is associated with the ability to cause infections and as such should be considered an important virulence determinant. Slime related infections are difficult to treat (Van Veen et al. 1992; Baillie et al. 1999; Cevahir et al. 2003; Cengiz et al. 2006).

Slime formation may be determined in several different ways, but most frequently it is demonstrated with the standard tube test, in which bacterial film lining a culture tube is stained with a cationic dye and visually scaled; with the microplate test, in which the optical density of the stained bacterial film is determined spectrophotometrically; or with the Congo red agar test (Christensen et al. 1982). Cevahir et al. (2003) investigated the slime production in Candida strains by these methods and they reported that the Congo red agar method is simple and practical for investigating slime production.

The aim of this study was to isolate yeasts from subclinical mastitic cows using standard methods in Aydin, Turkey, and to investigate the slime production from the isolated yeasts using Congo red agar method.

\section{Materials and Methods}

Diagnosis of mastitis

Clinical mastitis was diagnosed by changes in the udder and milk compositions. Changes in the udder included pain, swelling, warmth and abnormal appearance (blood tinged milk, watery secretions, clots, pus) of milk.

Cows that did not have clinical mastitis were subjected to further investigation for subclinical mastitis by using CMT. The procedures and interpretations were performed according to Quinn et al. (1994).

Milk samples

Milk samples were taken from the dairy farms located in Aydin. Aydin is a country of $8007 \mathrm{~km}^{2}$ by the Aegean Sea at the western part of Turkey. There are a total of 1740 farms and $70 \%$ of these farms have $\leq 10$ animals.

Within this study, CMT was done on 272 cows ( 1088 quarters). Twenty three dairy farms (5-16 cows per herd) were investigated from January 2008 to January 2009 in Adnan Menderes University Veterinary Faculty Microbiology Laboratories. The milk samples were always aseptically collected by veterinarians.

Isolation of microorganisms

The samples were plated onto 7\% sheep blood agar, MacConkey agar and Sabouraud dextrose agar. The plates were incubated at $37^{\circ} \mathrm{C}$ and examined for growth at 24, 48 and $72 \mathrm{~h}$ and at biweekly intervals for 4 weeks after which the plates showing no growth were considered negative.

Bacteria were identified by standard methods using morphological and biochemical characteristics (Holt and Kreig 1994; Carter and Cole 1995). When yeast growth was noticed, the yeast colonies were plated on Sabouraud agar, incubated at $37{ }^{\circ} \mathrm{C}$ for $48 \mathrm{~h}$ and investigated by Gram stain. The yeasts were identified on the basis of morphological, physiological, and biochemical characteristics, including "germ tube test", urease production, and carbohydrate assimilation. The genera and species of yeast were identified by API 20 C AUX system (bioMerieux, France).

Detection of slime by Congo red agar (CRA) method

The method developed by Freeman et al. (1989) was used in this study. The composition of CRA was brain heart infusion broth (BHIB) $37 \mathrm{~g} / 1$, glucose $80 \mathrm{~g} / 1$, agar $10 \mathrm{~g} / 1$, and Congo red $0.8 \mathrm{~g} / \mathrm{l}$. The Congo red stain was prepared as a concentrated aqueous solution and autoclaved separately at $121^{\circ} \mathrm{C}$ for 15 min and was added when the agar had cooled to $55^{\circ} \mathrm{C}$. Plates were inoculated and incubated aerobically at $35^{\circ} \mathrm{C}$ for $48 \mathrm{~h}$. Slime production was evaluated according to the "Congo red phenomenon". Isolates that produced dark red colonies were regarded as slime positive, whereas those showing pink or white colonies were slime negative.

\section{Results}

\section{Isolation of microorganisms}

A total of 339 milk samples from 152 subclinical mastitic cows were detected microbiologically for aerobic pathogenic microorganism. From 339 milk samples, 297 aerobic microorganisms were isolated and identified. Coagulase negative staphylococci (24.5\%), coagulase positive staphylococci (20.9\%), yeasts (12.1\%), Escherichia coli (9.8\%), Streptecoccus spp. (6.2\%), Bacillus spp. (5.6\%), Shigella spp. (3.5\%), Pseudomonas 
spp. (2.6\%), other bacteria (2.4\%) were isolated, and 12.4 showed no growth (Table 1$)$. Bacteria, especially staphylococci, were most frequently isolated as the main aetiological agent of subclinical bovine mastitis in the examined milk samples.

Table 1. Aetiological agents of bovine mastitis

\begin{tabular}{|l|c|c|}
\hline Aetiological agents & $\mathrm{n}$ & $\%$ \\
\hline Coagulase negative staphyloccci & 83 & 24.5 \\
\hline Coagulase positive staphylococci & 71 & 20.9 \\
\hline Yeasts & 41 & 12.1 \\
(*Candida spp. & $(34$ & $(10.0$ \\
**other yeasts) & 7 ) & $2.1)$ \\
\hline Escherichia coli & 33 & 9.8 \\
\hline Streptecoccus spp. & 21 & 6.2 \\
\hline Bacillus spp. & 19 & 5.6 \\
\hline Shigella spp. & 12 & 3.5 \\
\hline Pseudomonas spp. & 9 & 2.6 \\
\hline Other bacteria & 8 & 2.4 \\
\hline No growth & 42 & 12.4 \\
\hline Total & 339 & 100 \\
\hline
\end{tabular}

$\mathrm{n}$ - The number of isolated strains

Table 2. The genera and species of yeasts isolated from bovine mastitis

\begin{tabular}{|l|l|r|c|}
\hline Genera & Species & $\mathrm{n}$ & $\%$ \\
\hline \multirow{4}{*}{ Candida } & krusei & 15 & 36.6 \\
\cline { 2 - 4 } & kefyr & 12 & 29.4 \\
\cline { 2 - 4 } & guilliermondii & 3 & 7.3 \\
\cline { 2 - 4 } & famata & 2 & 4.9 \\
\cline { 2 - 4 } & utulis & 1 & 2.4 \\
\cline { 2 - 4 } & rugosa & 1 & 2.4 \\
\hline \multirow{3}{*}{ Trichosporon } & mucoides & 2 & 4.9 \\
\cline { 2 - 4 } & asahii & 1 & 2.4 \\
\hline \multirow{3}{*}{ Cryptococcus } & laurentii & 2 & 4.9 \\
\cline { 2 - 4 } & neoformans & 1 & 2.4 \\
\hline Saccharomyces & cerevisiae & 1 & 2.4 \\
\hline Total & 41 & & 100 \\
\hline
\end{tabular}

$\mathrm{n}$ : The number of isolated strains
Species of isolated yeasts

Yeasts were more commonly isolated agent than staphylococci. Forty one milk samples (12.1\% of total) were found positive for yeasts. The isolated yeasts were classified into the genera Candida, Trichosporon, Cryptococcus, Saccharomyces. Of total of 41 yeast species, $15(36.6 \%)$ were identified as C. krusei, 12 (29.4) C. kefyr, $3(7.3 \%)$ C. guilliermondii, $2(4.9 \%)$ C. famata, $1(2.4 \%) C$. utilis and C. rugosa, $2(4.9 \%) T$. mucoides, 1 (2.4\%) T. asahii, 2 $(4.9 \%) C$. laurentii, 1 (2.4\%) $C$. neoformans, $1(2.4 \%) S$. cerevisiae (Table 2).

\section{Slime production}

Fifteen strains $(36.6 \%)$ found as slime factor producer. Of the slime factor positive strains 7 were $C$. krusei, 4 C. kefyr, 1 C. guilliermondii, 1 C. famata, 1 C. laurentii, and $1 T$. asahii (Table 3).

\section{Discussion}

Infections by yeasts have been known both in animals and humans for years. Although the majority of mycotic mastitis in cows are mild, some cases may result in death. Excessive and erratic use of antibiotics, corticosteroids, immunosuppressive drugs and chronic diseases are the major contributing factors in increasing the incidence of diseases due to yeasts (Watts 1988; Van Veen and Kremer 1992).

In this study, 12.4\% (number/total number) of the bacteriological cultures were negative. In other studies it ranged from $7.3 \%$ to $38 \%$ (Arda ve İstanbulluoğlu 1979; Bartlett et al. 1992; Kuyucuoglu and Ucar 2001; Gianneechini et al. 2002; Tel et al. 2009). The reason may be attributed to a suspected anaerobic microorganism, a virus, mycoplasma.

Yeasts are microorganisms found in nature and isolated from diseased humans and animals. Among the yeast, Candida species are eukaryotic pathogens that are most commonly isolated from infections of dairy cows' mammary glands. Mycotic mastitis was first described in Turkey in 1979 (Arda and İstanbulluoğlu 1979). To our knowledge, slime production in yeasts isolated from bovine mastitis has not been studied in Turkey yet. 
Table 3. The distribution of slime positivity according to the isolated strains

\begin{tabular}{|l|c|}
\hline Species & Positive/n \\
\hline C. krusei & $7 / 15$ \\
\hline C. kefyr & $4 / 12$ \\
\hline C. guilliermondii & $1 / 3$ \\
\hline C. famata & $1 / 2$ \\
\hline C. utulis & $0 / 1$ \\
\hline C. rugosa & $0 / 1$ \\
\hline T. mucoides & $0 / 2$ \\
\hline T. asahii & $1 / 1$ \\
\hline C. laurentii & $1 / 2$ \\
\hline C. neoformans & $0 / 1$ \\
\hline S. cerevisiae & $0 / 1$ \\
\hline Total (\%) & $15 / 41(36.6)$ \\
\hline
\end{tabular}

Positive: the slime positive strains $\mathrm{n}$ : the number of isolated strains
The percentage of yeasts causing mastitis varies between countries. The percentage of yeast isolation carried out in many countries varies considerably, with $6.3 \%$ in Greece (BourtziHatzopoulou et al. 2003), $10 \%-17.3 \%$ in Brazil (Costa et al. 1993; Santos and Marin 2005) and 4.2\%-9\% in Poland (Krukowski et al. 2000; Krukowski et al. 2006). In the present study, it was $12.1 \%$.

There are many regional differences in yeast species causing mastitis. Many yeast species have been reported as causative agents of mastitis (Costa et al. 1993; Bourtzi-Hatzopoulou et al. 2003; Santos and Marin 2005; Krukowski et al. 2006; Seker 2010). Bourtzi-Hatzopoulou et al. (2003) reported that the yeasts isolated were classified into the genera of Candida, Geotrichum, Rhodotorula. Krukowski et al. (2000) reported that all the isolated yeasts were Candida, Trichosporon, Rhodotorula and in another study Krukowski et al. (2006) reported Candida, Trichosporon, Saccharomyces, and Rhodotorula. In the present study the yeasts isolated were classified into the genera of Candida, Trichosporon, Cryptococcus and Saccharomyces.

In studies conducted in Turkey, Candida species were isolated from 1-8.8\% of cows with mastitis (Arda and İstanbulluoğlu 1979; Beytut et al. 2002; Turutoglu and Mudul 2002; Tel et al. 2009). In the present study, the high isolation ratio (10.0\%) for Candida species may be attributed to the excessive humidity during the year and uncontrolled antibiotic use in Aydin region.

C. kruse i is the most commonly isolated strain in the present study. It is usually considered an agent responsible for environmental mastitis due to poor animal hygiene (Watts 1988). C. krusei was also the predominant species demonstrated by Farnsworth and Sorensen (1972), Santos and Marin (2005) and Seker (2010). This result was in accordance with our study. But Sheena and Siegler (1995) reported that C. krusei was isolated sporadically in bovine mastitis. In several countries, it was demonstrated that C. krusei, C. kefyr, C. rugosa and C. albicans were often responsible for mycotic mastitis (Farn sw orth and Sorensen 1972; Costa et al. 1993; Sheena and Siegler 1995; Santos and Marin 2005; Seker 2010). The geographical variations may be the reason for discrepancy in the distribution of species.

The yeasts were isolated in pure culture or mixed with bacteria. In the study $90 \%$ isolation rate as pure culture was higher than in other researches (Costa et al. 1993; Krukowski et al. 2000; Santos and Marin 2005).

Although C. albicans is frequently isolated, isolation of non-albicans Candida species strains has been frequently encountered in the past few decades. It has been known that non-albicans Candida strains have produced slime. It has been reported that the slime production by $C$. albicans was less frequent (42.9\%), than that by non-albicans Candida (63.4\%) (Vinitha and Ballal 2007). There is little information about slime production by the yeasts except $C$. albicans and $C$. parapsilosis in various clinical samples in humans in Turkey (Yakupoğullari and Toraman 2004). Kocazeybek et al. (2000) reported that the most frequently isolated species were C. albicans and C. krusei in mortal cases and in intensive care units in humans, respectively. Vinitha and Ballal (2007) reported that 34 Candida spp. were isolated from human blood, and C. krusei was the most commonly isolated species. 
Slime production by non-albicans Candida species was found in 25\% (Kalkanc1 et al. 1999 ) and in $35 \%$ (Birinci et al. 2005). In this study, 15 strains of C. albicans $(36.6 \%)$ produced slime.

In conclusion, yeasts such as Candida spp., Trichosporon spp., Cryptococcus spp., and Saccharomyces spp. were isolated from subclinical mastitic cows in Aydin in Turkey. $C$. krusei and $C$. kefyr were the most common isolated strains. It was detected that $T$. asahii, C. famata, C. laurentii, C. krusei, C. kefyr, C. guilliermondii strains had strong slime production. Increased slime production can lead to serious problems during therapy of infections caused by these yeast species.

\section{References}

Arda M, Istanbulluoglu E 1979: The studies on isolation and identification of aerobic and anaerobic bacteria, mycoplasma and fungi, and determination of the most effective antibiotics and fungicides against these microorganisms. Ankara Üniv Vet Fak Derg 26: 14-29

Baillie GS, Douglas LJ 1999: Candida biofilm and their susceptibility to antifungal agents. Methods Enzymol 310: $644-656$

Barlett PC, Miller GY, Lance SE, Heider LE 1992: Managerial determinants of intramammary coliform and environmental streptococci infections in Ohio dairy herds. J Dairy Sci 75: 1241-1252

Beytut E, Aydin F, Ozcan K, Genc O 2002: Pathological and bacteriological investigations on bovine mastitis in Kars region and its surrounds. Kafkas Univ Vet Fak Derg 8: 111-112

Birinci A, Cihan ÇÇ, Bilgin K, Acuner Ç, Durupinar B 2005: The investigation of slime production in Candida species. Turk Mikrobiyol Cem Derg 35: 163-166

Bourtzi-Hatzopoulou E, Zdragas A, Petridou E, Filiousis G 2003: Yeasts as a causative agent of bovine mastitis in Greece. J Hellenic Vet Med Society 54: 105-110

Carter GR, Cole JR 1995: Diagnostic procedures in veterinary bacteriology and mycology. 6th ed., Academic Press, California, USA, pp. 457-467

Cengiz AS, Us E, Cengiz AT 2006: The clinical importance of slime production. İnönü Üniv Tip Fak Derg 13: 193-197

Cevahir N, Demir M, Mete E, Kaleli I 2003: The investigation of slime production in Candida strains by different methods. Turkish J Infect 17: 67-70

Chahota R, Katoch R, Mahajan A, Verma S 2001: Clinical bovine mastitis caused by Geotrichum candidum. Vet Arhiv 71: 197-201

Christensen GD, Simpson WA, Bisno AL, Beachey EH 1982: Adherence of slime-producing strains of Staphylococcus epidermidis to smooth surfaces. Infect Immun 37: 318-326

Costa Eo, Gandra CR, Pires MF, Coutinho SD, Castinho SD, Castilho W, Teixeira CM 1993: Survey of bovine mycotic mastitis in dairy herds in the State of Sao Paulo, Brazil. Mycopathologia 124: 13-17

Farnsworth RJ, Sorensen DK 1972: Prevalence and species distribution of yeast in mammary glands of dairy cows in Minnesota. Can J Comp Med 36: 329-332

Freeman DJ, Falkiner FR, Keane CT 1989: New method for detecting slime producing by coagulase negative staphylococci. J Clin Pathol 42: 872-874

Gianneechini R, Concha C, Rivero R, Delucci I, Lopez MJ 2002: Occurrence of clinical and sub-clinical mastitis in dairy herds in the west littoral region in Uruguay. Acta Vet Scand 43: 221-230

Holt GJ, Kreig NR 1994: Bergey's Manual of Determinative Bacteriology, $9^{\text {th }}$ edn. Baltimore, USA: Williams and Wilkins, pp. 175-561

Kalkanci A, Çirak YM, Mansuroğlu H, Kuştimur S 1999: The determination of slime factor in Candida species. Turk Mikrobiyol Cem Derg 29: 183-185

Kocazeybek B, Ordu A, Ayyildiz A, Arslan M, Bayindir O, Sonmez B 2000: The yeasts isolated from intensive care unit. Turk Mikrobiyol Cem Derg 30: 38-40

Krukowski H, Tietze M, Majewski T, Rozanski P 2000: Survey of yeast mastitis in dairy herds of small-type farms in the Lublin region, Poland. Mycopathologia 150: 5-7

Krukowski H, Lisowski A, Rozanski P, Skorka A 2006: Yeast and algae isolated from cows with mastitis in the south-eastern part of Poland. Pol J Vet Sci 9: 181-184

Kuyucuoglu Y, Ucar M 2001: Determination of the subclinical and clinical mastitis rates in dairy cows, of Afyon region and effective antibiotics. Vet Hek Mikrobiyol Derg 1: 19-24

Leslie KE, Jansen JT, Lim GH 2002: Opportunities and implications for improved on farm cowside diagnostics. Proc DeLaval Hygiene Sym, pp: 147-160

Philpot WN, Nickerson SC 1991: Mastitis attack. Surge International-Babson Bros Co Naperville, Illinois, USA, pp: $10-28$

Quinn PJ, Carter ME, Markey BK, Carter GR 1994: Clinical Veterinary Microbiology. Mosby-Year Book Europe Limited, Lynton House, London, England pp: 40-190 
Santos RC, Marin JM 2005: Isolation of Candida spp. from mastitic bovine milk in Brazil. Mycopathologia 159: $251-253$

Sheena A, Siegler L 1995: Candida krusei isolated from a sporadic case of bovine mastitis. Can Vet J 36: $365-365$

Seker E 2010: Identification of Candida species isolated from bovine mastitic milk and their in vitro hemolytic activity in western Turkey. Mycopathologia 169: 303-308

Tel OY, Keskin O, Zonturlu KA, Kaya NBA 2009: Subclinical mastitis prevalence and determination of the antibiotics susceptibility in Șanlıurfa region. FÜ Sağ Bil Vet Derg 23: 101-106

Turutoglu H, Mudul S 2002: Is Escherichia coli O157: H7 an etiological agent of bovine mastitis. Isr J Vet Med 57: $82-83$

Vinitha M, Ballal M 2007: Biofilm as virulence marker in Candida isolated from blood. World J Med Sci 2: $46-48$

Yakupoğullari Y, Toraman ZA 2004: Investigation of slime factor production in Candida strains isolated from various clinical samples. Turk Mikrobiyol Cem Derg 34: 178-181

Yücel A, Kantarcioğlu AS 2000: Pathogenicity determinants of Candida. Cerrahpasa J Med 31: 172-186

Van Veen HS, Kremer WD 1992: Mycotic mastitis in cows. Tijds Diergennsk 117: 414-416

Watts JL 1988: Etiological agents of bovine mastitis. Vet Microbiol 16: 41-66 